
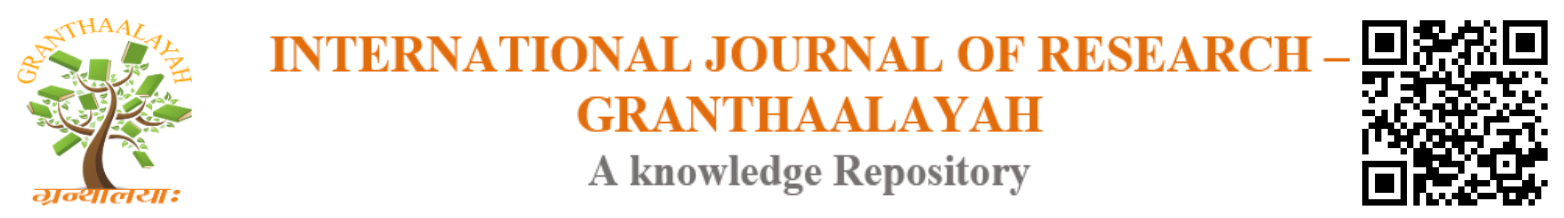

Management

\title{
ENTREPRENEURSHIP EDUCATION IN TERTIARY INSTITUTIONS: A PARADIGM FOR SUSTAINABLE DEVELOPMENT
}

\author{
Dr. Okoye Victor O ${ }^{1}$, Okoye Chinasa R. ${ }^{2}$ \\ ${ }^{1}$ Department of Banking and Finance, School of Financial Studies, Federal Polytechnic Oko, \\ Anambra State, Nigeria \\ ${ }^{2}$ Department of Social Sciences, School of General Studies, Federal Polytechnic Oko, Anambra \\ State, Nigeria
}

\begin{abstract}
The paper attempts to highlight the importance of entrepreneurship education in the quest for sustainable development and the role of tertiary institutions in promoting sound entrepreneurship education. In Nigeria, just like other developed and developing countries, tertiary institutions, through research and innovation, have been saddled with the responsibility of integrating sustainable development into their teachings and learnings. As societies look for solutions that could lead to sustainable development, entrepreneurship education, being offered in tertiary institutions, is becoming increasingly more appealing. Thus, given their primary role as knowledge producers, tertiary institutions, through research and innovation, can serve as powerful means to help create a more sustainable future by engaging in entrepreneurship education. Going forward, this paper also highlights the role of tertiary institutions in this very important subject of sustainable development, the reasons why people choose to be entrepreneurs as well as the importance of entrepreneurship education. The paper concludes by proffering suggestions on the way forward.
\end{abstract}

Keywords: Tertiary Institutions; Entrepreneurship Education and Sustainable Development.

Cite This Article: Dr. Okoye Victor O, and Okoye Chinasa R.. (2019). "ENTREPRENEURSHIP EDUCATION IN TERTIARY INSTITUTIONS: A PARADIGM FOR SUSTAINABLE DEVELOPMENT." International Journal of Research - Granthaalayah, 7(9), 63-70. https://doi.org/10.29121/granthaalayah.v7.i9.2019.560.

\section{Introduction}

The connection between entrepreneurship and sustainable development is particularly relevant as most businesses attempt to reconcile the sustainability aspects with profitability. This nexus is important and of great interest for the academia, scientific community and even policy makers. This paper attempts to highlight the role of tertiary institutions in promoting sustainable development through emphasis on entrepreneurship education. Entrepreneurship Education for sustainable development enables all individuals to critically develop the knowledge, perspectives, 
values and skills needed to take part in decisions to improve the quality of life, locally and internationally. Given their primary role as knowledge provider, tertiary institutions can serve as a powerful means to help create a more sustainable future through a rigorous entrepreneurship education. Following strongly on this assumption, the concept of 'education for sustainable development 'has become, in recent years, one of the core educational initiatives to help to address many of the problems associated with human development. As a matter of fact, tertiary institutions role in creating a sustainable future through research and innovation anchored in entrepreneurship education will presumably take on a greater importance as the world continues to become increasingly globalised and interdependent.

\section{Sustainable Development}

The United Nations defines sustainable development in Bruntland report (1987) as quoted in Mihaela, K (2012) “...development that meets the needs of the present without compromising the ability of future generations to meet their own needs". Blessinger P et al (2018) noted that sustainable development not only deals with environmental

issues, but economic, social and cultural issues as well. Given the increased demands placed on societies and the environment due to, among other factors, increased human migration, increased urbanisation and industrialisation as well as the ongoing depletion of non-renewable resources, it is clear that global action is needed to create a more sustainable future.

Palmer J, (2013) sees sustainable development as a dynamic and evolving concept with many dimensions and interpretations. According to her, the concept is open ended that it can be interpreted in many different ways. She further asserts, the various interpretations often reflect not only contextual, but ideological differences.

For Mohammed S. M et al, (2016), the main issue is to use the idea of sustainable development to reflect on the nature of our world (including development and environmental issues, vulnerability and risk) on key emerging responses to what is wrong and how we should work towards improvement (sustainability).

Reacting to the Brundtland report (1987) mentioned above, Mihaela K (2012) maintains that such definition requires an understanding of the complex interplay of environmental, economic, and social processes at different scales, from local to global. Since its appearance and up to present, the concept of sustainable development has known a continuous improvement by adding new coordinates, theoretical, methodological and practical valences. Yet, a clear, fixed and immutable meaning remains elusive and reality surely proves that.

\section{Role of Tertiary Institutions in Sustainable Development}

Most tertiary institutions have stepped up their activities in the efforts to support sustainable development by introducing new programmes and courses related to education for sustainable

development. It is on record that most tertiary institutions collaborate with other development partners to share knowledge, generate activities and develop strategies and methodologies to 
improve sustainable development. According to Mohammed S.M et al (2016) tertiary institutions play important role in generating new knowledge that shapes and influences the decisions made by government, policy makers and other stakeholders through research and innovation.

For Blessing P et al, (2018) "Development "empowers people to change the way they think and work towards a sustainable future". It therefore involves making access to good-quality education available at every stage of life.

More specifically, it involves educating students on the necessity of sustainable development by integrating sustainable development issues into all aspects of teaching, research and service.

In practice, it means equipping students with the requisite knowledge, skills, attitudes and values to create a sustainable future. To that end, students should cultivate critical and creative thinking skills, engage in authentic interdisciplinary learning activities and develop a value system that emphasises responsibility to self, others and the planet. Based on these assumptions, it becomes imperative to underscore that one area that has attained some measure of prominence is the area of entrepreneurial education.

\section{Entrepreneurship}

According to Wikipedia, online publication, entrepreneurship is the process of designing, launching and running a new business, which is often initially a small business. The people who create these businesses are called entrepreneurs.

Entrepreneurship has been described as the "capacity and willingness to develop, organize and manage a business venture along with any of its risks in order to make a profit. While definitions of entrepreneurship typically focus on the launching and running of businesses, due to the high risks involved in launching a start-up, a significant proportion of start-up businesses have to close due to lack of funding, bad business decisions, an economic crisis, lack of market demand, or a combination of all of these.

A broader definition of the term is sometimes used, especially in the field of economics. In this usage, an Entrepreneur is an entity which has the ability to find and act upon opportunities to translate inventions or technologies into products and services: "The entrepreneur is able to recognize the commercial potential of the invention and organize the capital, talent, and other resources that turn an invention into a commercially viable innovation. In this sense, the term "Entrepreneurship" also captures innovative activities on the part of established firms, in addition to similar activities on the part of new businesses.

\section{Why do People Become Entrepreneurs?}

Every entrepreneur has his/her own 'why' that drove him/her to dive into being his/her own boss. Whether entrepreneurs need more freedom or to make the world a better place, they all take control of their life by living life on their own terms. Here are a few of the reasons why people become entrepreneurs: 
To Change the World: Many entrepreneurs strive to make the world better. Whether entrepreneurs believe in space exploration, eliminating poverty or creating a practical but gamechanging product, they ultimately build a brand in service of others.

Some entrepreneurs use their business as a way to raise capital quickly to funnel into their noble causes. To social entrepreneurs, building an empire is about creating a better world for everyone.

They do Not Want A Boss: Entrepreneurs often struggle with having a boss. They often feel suffocated, restricted and held back. Some entrepreneurs may feel that they have a more effective way of doing things. Others may dislike the lack of creative freedom. Ultimately, they become attracted to entrepreneurship to succeed on their own terms. Being the boss can be more fulfilling than having one.

They Want Flexible Hours: Entrepreneurship is often popular around those who need flexible hours. Many people with disabilities often enjoy entrepreneurship as it allows them to work when they're able to. Parents with young children might also prefer entrepreneurship as it allows them to raise young children at home or pick them up from school without having to feel guilty about it.

They Want to Work from Anywhere: Along with flexibility in working hours, entrepreneurship is popular among those who don't want to be tied down to a specific location. Entrepreneurs might not want to work from the same place every single day, as it might get boring for them. So, if you're looking for the freedom to work from anywhere in the world, maybe the entrepreneur lifestyle is the right one for you.

They are Risk-Takers: Calculated risk taking and entrepreneurship go hand in hand. Entrepreneurs don't apply to jobs, they create them. With that comes risk. Whether it's the financial risk of starting your first brand or the risk from not knowing what to expect, business is risky. Entrepreneurs are often taking risks by trying new things.

They Cannot Get A Job: Many stumble into entrepreneurship when they can't get a job. Getting fired, a lack of experience or a criminal record can prevent the average person from getting a job when they're desperate. Instead of being defeated by their situation,

they create new opportunities for themselves. A new graduate might start an online store the summer after graduation to build up their resume. A parent who is seasonally laid off each winter might start a business to ensure they can continue feeding their family while keeping a roof over their heads.

They do Not Fit into The Corporate Environment: Entrepreneurs don't often thrive in corporate environments. It's often very restricting for their growth. They may dislike the lack of control they have in their role or the office politics. In general, you can spot an entrepreneur in a corporate environment as they're usually trying to gain more control in their role and learning their coworkers responsibilities to better understand how everything fits together.

They are Curious: Entrepreneurs love finding out the answer to the question, 'what will happen if...' They're experimental. Entrepreneurs love learning. They regularly read business books to advance their knowledge. So naturally, entrepreneurship appeals to them because doing allows them to learn the most in the shortest amount of time. Their curiosity allows their continued growth.

They are Ambitious: Those who love reaching difficult goals and milestones are made to be entrepreneurs. There's no limit to how much an entrepreneur can make and so they 
can always work to achieve higher levels of greatness. Since there's no limit to what they can achieve, entrepreneurs constantly find themselves growing and achieving more than they ever imagined. When obstacles get presented in front of them, they find the workaround to their goal. Entrepreneurs are unstoppable.

\section{Entrepreneurship Education: Federal Polytechnic Oko Example}

According to Bandele S. O, (2013) entrepreneurship education is the process through which learners acquire a broad set of competencies in individual to bring social and economic benefits. It seeks to provide students with the knowledge, skills and motivation to encourage entrepreneurial success in a variety of settings. Variations of entrepreneurship education are offered at all levels of schooling from primary or secondary schools through graduate programs. According to UNESCO/ILO (2006), entrepreneurship education has been defined as "a collection of formalized teaching that informs, trains, and educates anyone interested in participating in socioeconomic development through a project to promote entrepreneurship awareness, business creation, or small business development. It aims at fostering self-esteem and confidence by drawing on the individual's talents and creativity, while building the relevant skills and values that will assist students in expanding their perspectives on schooling and opportunities beyond.

For entrepreneurship education to be effective in developing the competences of learners, the capacity of schools, especially, tertiary institutions, to create supportive and stimulating learning environments is as important as the personal competences and motivation of educators. This is because, entrepreneurship education cannot take place in isolation from the world outside of the school. It may require working in partnership with external organisations in order to facilitate learning and this is where the Federal Polytechnic Oko example comes in handy.

In recognition of the importance of entrepreneurial education as being pivotal to the attainment of sustainable development, Federal Polytechnic Oko has established a centre for entrepreneurship education known as EED Centre headed by a Director. Students of the polytechnic, compulsorily, go through the programmes of the directorate during their National and Higher National Diploma years. The programmes emphasize on practical knowledge where students are divided into groups and resource persons engaged to take them on processes and procedures in production of tangible commodities. The main aim of this programme is to equip the students with the requiste practical knowledge that would be of help to them in future. Most students who passed throught his programme do not find it difficult to intergrate themselves into the larger society where such practical knowledge is needed.

\section{Importance of Entrepreneurship Education}

It is important to learn and study entrepreneurship because the future is uncertain and it is only creators and innovators that such uncertain future belongs to. Entrepreneurship education serves as an excellent foundation for the types of creative, innovative ideas we need to succeed in the 21 st century. Below are some of the reasons why entrepreneurship education is so important and essential in our bid to attain sustainable development as espoused by Nathan Barber, (2014) 


\section{Nurtures Personal Growth and Development}

Studying entrepreneurship benefits students and learners from different social and economic backgrounds because it teaches people to cultivate unique skills and think outside the box. Moreover, it creates opportunity, instills confidence, ensures social justice and stimulates the economy. Entrepreneurship education also provides budding entrepreneurs with the skills and knowledge to come up with business ideas and develop their own ventures.

\section{Relevance}

The advantage of learning entrepreneurial skills over more traditional subjects is that they are not uniquely relevant to a career as an entrepreneur. The skills needed to start one's own business are relevant in any field and would also be desirable attributes for being an employee. In fact, having a wide range of business-relevant skills acquired through studying entrepreneurship would make one an ideal candidate in most fields. Therefore, skills taught in entrepreneur courses generally apply to all areas of industry and do not kill creativity or block opportunity to a specific career.

\section{Tap into Unrealized Talents}

Standard education programs ranging from elementary schools to universities are optimized to reflect the "education for everyone" model. While the idea behind this movement is great and essentially good, it does not mean that it brings out the best in the students. Many students float away from their talents because they are pushed to study courses where they do not have some comparative advantage. Learning entrepreneurship is very different from learning anything else. The very concept of the program is to help the students identify their strengths and talents and to work on improving them. In real-world examples, we can see many successful entrepreneurs who were very bad students in their time. Both Mark Zuckerberg and Bill Gates are college dropouts but successful entrepreneurs impacting positively on the society.

\section{Risk is Something to Live With}

Another important lesson that entrepreneurship programs teach students is that risk is something natural, something that we have to live with, and something that has to be managed. There is no other school program that teaches this. In the world of business, risk is a common occurrence. And to be able to succeed in it, one has to work on one's character traits - risk-taking and persistence. An entrepreneurship program fosters these character traits. This is why it is beneficial for students when they find themselves in a real-life situation.

\section{Critical Thinking}

The ability to think critically is essential to one's success in the world of business. Learning entrepreneurship exposes students to numerous opportunities to learn how to think critically and analyze the pieces on the board. Being aware of all the important factors and seeing how they affect each other is the foundation of a smart decision-making process. This is not something that can be learned from a book. Students have to be exposed to real-world examples and learn from their own experience.

\section{Benefits to Society}

Skills associated with entrepreneurs, such as financial literacy, money management, and strong interpersonal skills are not only beneficial but also relevant for day-to-day life. Nonetheless, the benefits of entrepreneurship studies go beyond being purely personal; they are also beneficial to 
society. The economic benefits of entrepreneurs to society has never been in doubt. New enterprise and entrepreneurial innovation are critical for any society to be globally competitive, with technological advancements creating new jobs.

\section{Be Able to Make a Difference}

The world has never been more in need of students who are trying to make a difference than it is today. And this is the very definition of entrepreneurs. Yes, their goal is to sell products and services, but this is just one piece of the entire puzzle. To become successful at it, they have to identify the real needs and problems of people and solve them. Even fresh out of the entrepreneurship education program, the students have this unique mindset: find problems that need to be solved, invent a solution for them, and, ultimately, make the world a better place.

\section{Preparedness for Real Life}

As our education system becomes plagued with rigid testing and standards, opportunities to innovate, collaborate and demonstrate proficiency in real life situations become rare. In addition to encouraging people, entrepreneurship education requires students to be innovative, creative and collaborative with others.

If our current society is to benefit from the entrepreneurship education, it's only fair that we equip ourselves with the training to do so. On the flip side, the personal benefits of studying entrepreneurship spread far beyond the business world leading to an arguably more prosperous livelihood. It goes without saying that we as a society should be doing more to help develop our entrepreneurial minds.

\section{Recommendations}

In view of the foregoing, the following recommendations are proffered.

1) To achieve a desirable climate that sustains entrepreneurship education in our tertiary institutions there is the need to design curriculum to be responsive to the needs of the society. Such curriculum will not only lay emphasis on impacting knowledge but also on the willingness to restructure the ends and means of instruction.

2) There is the need to recognize the importance of technology and its relevance in learning experiences as society stands to benefit more from such functional entrepreneurship education.

3) There is the need to get the staff of these tertiary institutions adequately motivated to engage in research that would lead to a more pragmatic entrepreneurship education which would benefit the society over time.

4) The government has a role to play by ensuring that a conducive atmosphere through legislation and policy thrust that encourage entrepreneurs to thrive is put in place.

5) Sponsorship to workshops, conferences and trainings of staff in entrepreneurship trainings in tertiary institutions should be put in place in order to acquaint them with latest trends in entrepreneurship education. 


\section{Conclusion}

Tertiary institutions play important and prominent roles in promoting education for sustainable development by providing the requisite knowledge through entrepreneurship education. Entrepreneurship education should lead to key competences which refers to an individual's ability to turn ideas into action. This includes creativity, innovation, risk-taking and ability to plan and manage projects in order to achieve objectives that would lead to sustainable development. There have been significant efforts to address sustainability in teaching and learning through research and innovation on the part of most tertiary institutions such that tertiary institutions that have not yet keyed into this programme should be encouraged to design their curriculum to accomodate entrepreneurship education.

\section{References}

[1] Bandele, S.O (2013) "Entrepreneurship Education: A Priority for Higher Education Institutions" International Tertiary Institution Top Executive Workshop, Accra, Ghana.

[2] Blessing, P (2018) "Higher education's key role in sustainable development" Paper presented at the International Higher Education Teaching and Learning Association Conference, South Africa.

[3] Mihaela, K (2012) "The Relationship between Entrepreneurship, Innovation and Sustainable Development. Research on European Union Countries." Online publication at www.sciencedirect.com

[4] Mohammed, S. M (2016) "Rethinking Education for Sustainable Development: The Role of Tertiary Institutions In Nigeria" Book of Tropical Educational Issues. Published onlineoer.udusok.edu.ng

[5] Nathan, B., (2014) 'Importance of Entrepreneurship Education" Published in twitter handle @_nathanbarber

[6] Palmer, J (2013) "Education for Sustainable Development: The Role of Tertiary Institution in Nigeria". Academic Journal of Inter-disciplinary Studies, published online at www.meser.org/journal/index.php/ajis/article/download

*Corresponding author.

E-mail address: okoyevictor26@ yahoo.com/ochina@ yahoo.com 